\title{
On the Representation of Ganymede in the Roman Mosaic of the Loves of Zeus from Astigi (Baetica)
}

\section{Astigi'den (Baetica) Zeus'un Așkları Konulu Roma Mozaiğinde Ganymedes'in Tasviri Üzerine}

Luz NEIRA JIMÉNEZ*

(Received 16 October 2019, accepted after revision 07 August 2020)

\begin{abstract}
The discovery in 2015 of the great mosaic so called of the Zeus' Loves in Écija (Sevilla) comes to highlight again the quality of the mosaic heritage of the ancient Astigi, capital of the conventus astigitanus in Baetica. It is a large pavement, which contains several pictures, with geometric motifs, Bacchic themes and scenes from the Zeus Loves cycle, among which the legend of the Rape of Europe stands out, as well as one of the Dioscuri, Leda and the Swan, a satyr pursuing a young maiden, identified as Antiope, and by last the legend of Ganymede.

The depiction of Ganymede in Roman mosaics is well documented, in particular the precise instant of the abduction with both already in flight. However the Ganymede's legend in the Astigi pavement of the Zeus 'Loves found in the Plaza de Armas shows a not usual image. This article deals with the literary sources and possible parallels that would have served as a model for the representation from Astigi.

Are analyzed several images in Attic red-figure vases, Roman paintings, reliefs and gems and particularly in two mosaic floors, the Antioch pavement of the so called domus of Buffet Supper and the Italica mosaic of the love stories of Zeus, preserved in the Lebrija Palace-Museum in Seville.
\end{abstract}

Keywords: Roman mosaic, Astigi, Zeus, loves, Ganymede.

Öz

2015 yılında Écija'da (Sevilla) Zeus'un Aşkları adlı büyük mozaiğin bulunması, Baetica'daki conventus astigitanus'un başkenti olan antik Astigi'nin mozaik mirasının kalitesini tekrar göz önüne sermiştir. Bu mozaik, aralarında Europe'nin Kaçırılması efsanesinin yanı sıra Dioskur, Leda ve Kuğu, Antiope olarak tanımlanan genç bir bakireyi kovalayan satyr ve Ganymedes efsanesi olmak üzere Zeus'un aşk döngüsünden manzaralar, Bacchus temaları, geometrik motifler ve birtakım resimler içermektedir.

Ganymedes'in Roma mozaikleri içindeki tasviri, özellikle her ikisi de uçuş halinde olan kanatlart ile kız kaçırma anı olmak üzere kesin olarak belgelenmiştir. Ancak Ganymedes'in Plaza de Armas 'ta bulunan Astigi döșemelerindeki Zeus'un Aşkı mozaiğinde tasvir edilen efsanesi olağan olmayan bir görüntü göstermektedir. Bu makale, Astigi'nin temsiline örnek teşkil edecek edebi kaynaklar ve olası paralelliklerle ilgilidir.

Attika'daki kırmızı figürlü vazolar, Roma resimleri, rölyefleri ve yüzük taşları (gemler), özellikle Akşam Yemeği domusu olarak adlandırılan Antakya mozaik döșemesi ve Sevilla'daki Lebrija Sarayı Müzesi'nde korunan Zeus'un aşk hikâyelerini tasvir eden İtalyan mozaikleri olmak üzere iki mozaik zemin döşemesi analiz edilmiştir.

Anahtar Kelimeler: Roma mozaiği, Astigi, Zeus, aşklar, Ganymedes.

\footnotetext{
" Luz Neira Jiménez, Universidad Carlos III de Madrid, Getafe, Madrid, Spain. (iD https://orcid.org/0000-0002-2421-6792. E-mail: lneira@hum. uc3m.es

This work is the result of the research carried out in the $\mathrm{R}+\mathrm{D}+\mathrm{i}$ Project. CORPVS VRBIVM BAETICARUM (I) (CVB) funded by the Consejería de Ciencia y Tecnología de la JUNTA DE ANDALUCÍA under the direction of Prof. Juan Campos of Huelva University.
} 
The find of a spectacular Roman mosaic on the site of the Plaza de Armas of the Alcazar de Écija (Seville) on the hill of San Gil or "Picadero" in 2015, came to enlarge the extraordinary archaeological heritage of Astigi Colonia Augusta Firma, capital of the conventus astigitanus in Baetica. According to its excavator, Dr. Sergio García Dils ${ }^{1}$ (Municipal office of Archaeology), co-author of a monograph recently published on the pavement and its archaeological context (García Dils de la Vega - Ordoñez 2019), this mosaic originally paved a room, about of $40 \mathrm{~m}^{2}$, identified as triclinium of a domus, to which also belonged the well-known mosaic of the double Bacchic head and the mosaic of the very fragmentary maenad, in addition to another very damaged one (Vargas et al. 2017: nos. 34-37). After having been restored in the Andalusian Institute of Historical Heritage, the mosaic has been placed again in situ at the end of 2019, where I had the opportunity to see it thanks to the courtesy of Sergio García-Dils de la Vega.

In my study on Roman mosaics urbium of the conventus hispalensis and astigitanus $^{2}$, we have analyzed this mosaic (Neira 2018: 417-444 fig. 12), some of whose scenes have also been the subject of interest in another work on mosaicscraftsmen workshops and cartons in Baetica (Neira 2019: 349-359).

We must note that the large mosaic of the Zeus' Lovers (Fig. 1) shows and unusual composition formed by two inverted/opposed L's. The surface of figured areas is slightly bigger than those of geometrical figures. This figured surface shows the above mentioned conjunction of Bacchic scenes with other mythological topics. A rectangular panel, disposed as a frieze, has a central scene reproducing satyrs performing the grape tread. In the left side of this scene we can recognize a female figure laying down close to a child, while in the right side we can see goat approaching a vine in front of two men that seem to be surprised. In a second figured area of this mosaic, we can recognize the representation of the rape of Europe and, in the pictures that acted as framework of three sides of this

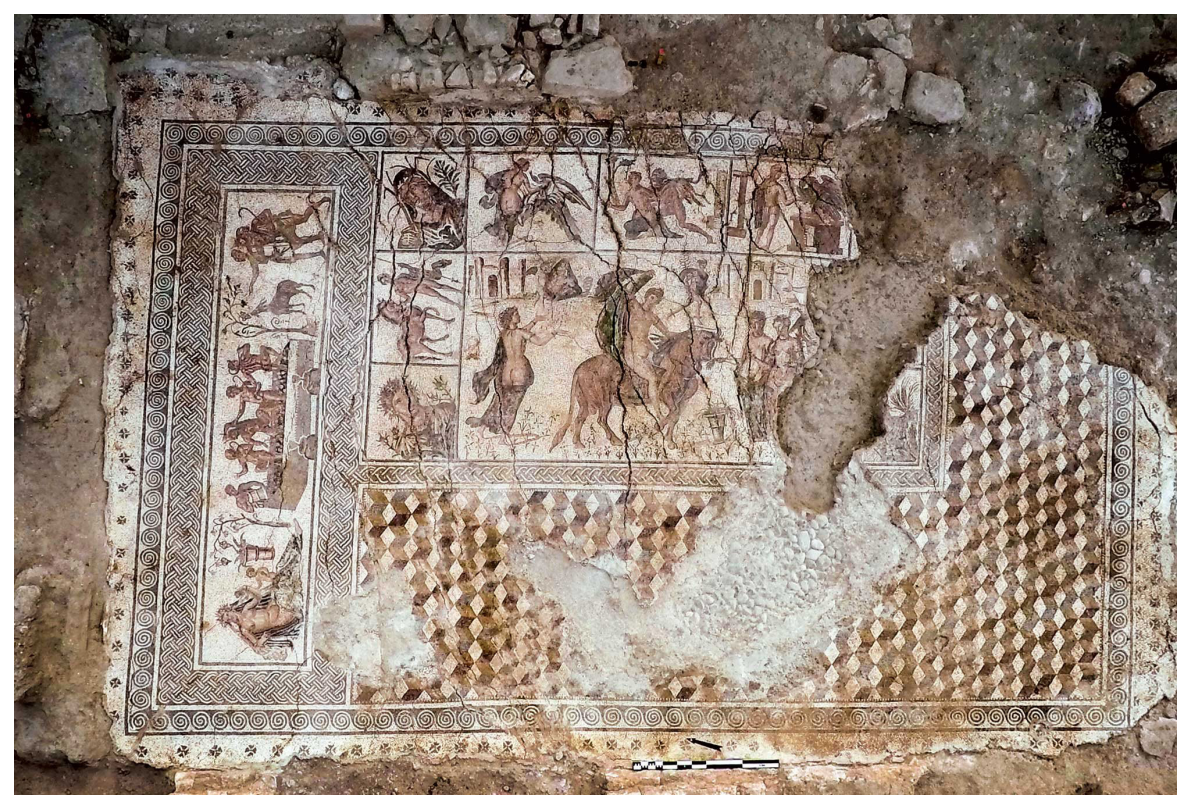

1 I would like to express in these lines all my thanks to Dr. Sergio García-Dils de la Vega for his kindness in sending me images with high-resolution details and information about the mosaic.

2 Result of the aforementioned project J. Bermejo, J. Campos, coords., Corpus Urbium Baeticorum. Conventus hispalensis and astigitanus, I- II. Huelva, Onoba Monographs, 2.
Figure 1

Mosaic of the Rape of Europe and the Loves of Zeus. Astigi (Écija). Photo: According to Juan Ignacio Rojano / RCFilms (History. National Geograhic 140). 
pavement, the busts of the Four Seasons are placed filling the squares ${ }^{3}$. Scenes alluding to other Zeus' loves including the Dioscuri, Leda and the Swan, a satyr pursuing a maenad identified as Antiope and Ganymede.

As it is known, the joint display of the loves is not uncommon in Roman mosaics, although the repertoire of "loves" chosen to decorate a mosaic is not always identical, documenting as the newest aspect of the Astigi mosaic ${ }^{4}$ studied in these lines the obvious subordination of several of the images of the Loves - one of the Dioscuri, Leda, Antiope and Ganymede - to one of them, that of the legend of Europe, when they are inscribed in several boxes as a U-frame inverted around the rectangular field with the depiction of one of the episodes of the Rape, which monopolizes the main scene.

Most of these pictures represent a widely documented iconography in Roman mosaics. Particularly similar to other parallels is the figure of Leda (Blázquez 1999: 555-65), giving her back to the viewer, showing her hams thanks to the strategic position of a long robe that only covers her legs. This figure shows the profile of her head, apparently taking the initiative, attracting the Swan to her lips while taking the neck of the bird firmly. This figure has its most closer parallel in the Leda's mosaic from Astigi (Écija, Seville) (San Nicolás 1999: 370-371 figs. 18-19; San Nicolás 2005: 975-985). The similarity of both models suggest the use of common models for both pavements. This is also attested in the reproduction of the Antiope, reproduced in the moment of the harassment when the god is turned into satyr ${ }^{5}$. The figuration of the main scene of the field with the Rape of Europe is striking, because far from including only Europe and the Bull, whether it is still on land, whether it is already in full marine crossing, the most widespread synthetic image without a doubt, perhaps accompanied by an eros or at most by one of the maidens who were next to the Phoenician princess at the seashore, as in most of the mosaics (Wattel de Croizant 1995; López Monteagudo - San Nicolás 1995: 424-438), the depiction of the legend shows a great profusion of details and figures, both by including more precise references to the scene in which it takes place, as to the number of characters that are part of the scene, completely unusual in Roman mosaics. In this regard,

3 The four squares located in the corners had to contain in origin the busts of the Four Seasons, although only those of the left side, that of the Spring, have been preserved according to the floral headband and the roses that flank it, and the one of the Winter, by the mantle on the head and the stems of elongated and dry leaves, typical of this season, as well as some spikes of the lower right frame that would allude to Summer, completely missing the one of the upper right corner, which would have contained the bust of the Autumn, reproducing the cycle of the Seasons a radial arrangement in the opposite direction to the movement of the hands of the clock, from the lower left frame to the upper left (Neira 2018: 21).

4 One of the most complete in the well-known Italica pavement preserved in the collection of the Palace-Museum Countess of Lebrija, from the second half of the $2^{\text {th }}$ century AD (Blanco 1978: no. 1), and in smaller numbers, in mosaics, among others, of Palermo and Ouled Agla (Numidia), currently in the Algers Museum, already from the $4^{\text {th }}$ century AD (Wattel-de Croizant 1995: 217-220 table 29a), where, in the latter, Europe, Leda, Antiope, Ganymede and Danae coincided, but without the presence of one of the Dioscuri, however, in a rectangular field without compartmentalization some, in which the representative image of each "love" shows the same role. Likewise, the joint representation of scenes alluding to the legend of two Lovers is well attested without going any further in the mosaics from Astigi, specifically in one of the pavements of the Roman domus of San Juan Bosco street, where in the same field rectangular images of the abduction of Europe and Ganymede appear (López Monteagudo 2001: 130-146).

5 As in the mosaics from Italica, Thysdrus and Thamugadi, from the $2^{\text {nd }}$ and early $3^{\text {rd }}$ centuries, and Antiocheia (San Nicolás 2010: 500-503 figs. 3-6), although in the Italica copy and the Thysdritan Antiope it appears of backs, while on the pavement of the caldarium of the Philadelfi hot springs in Thamugadi and in the Antioch the maiden is also kneeling but facing the viewer, seen from three quarters, carrying a tympanum in a rugged setting indicated by a tree, with whose depitions are more similar to the scene of Écija's mosaic, although the crack that affects this part of the pavement prevents us from appreciating with certainty whether Antiope also carried the same musical instrument in his right hand. 
it is obvious that it is the initial episode of the legend, with precise indication in the upper area of the field, in the background, of two groups of architectural buildings, with the presence, novel, of an eros, next to the image of a mature and bearded bust covered by a mantle, perhaps Zeus, on which we will return later, and Hermes, respectively, and on the lower part in the foreground the numerous flowers, which, according to the ancient authors, were collecting Europe and its servants, when they were surprised by the appearance of a bull (Fig. 2).

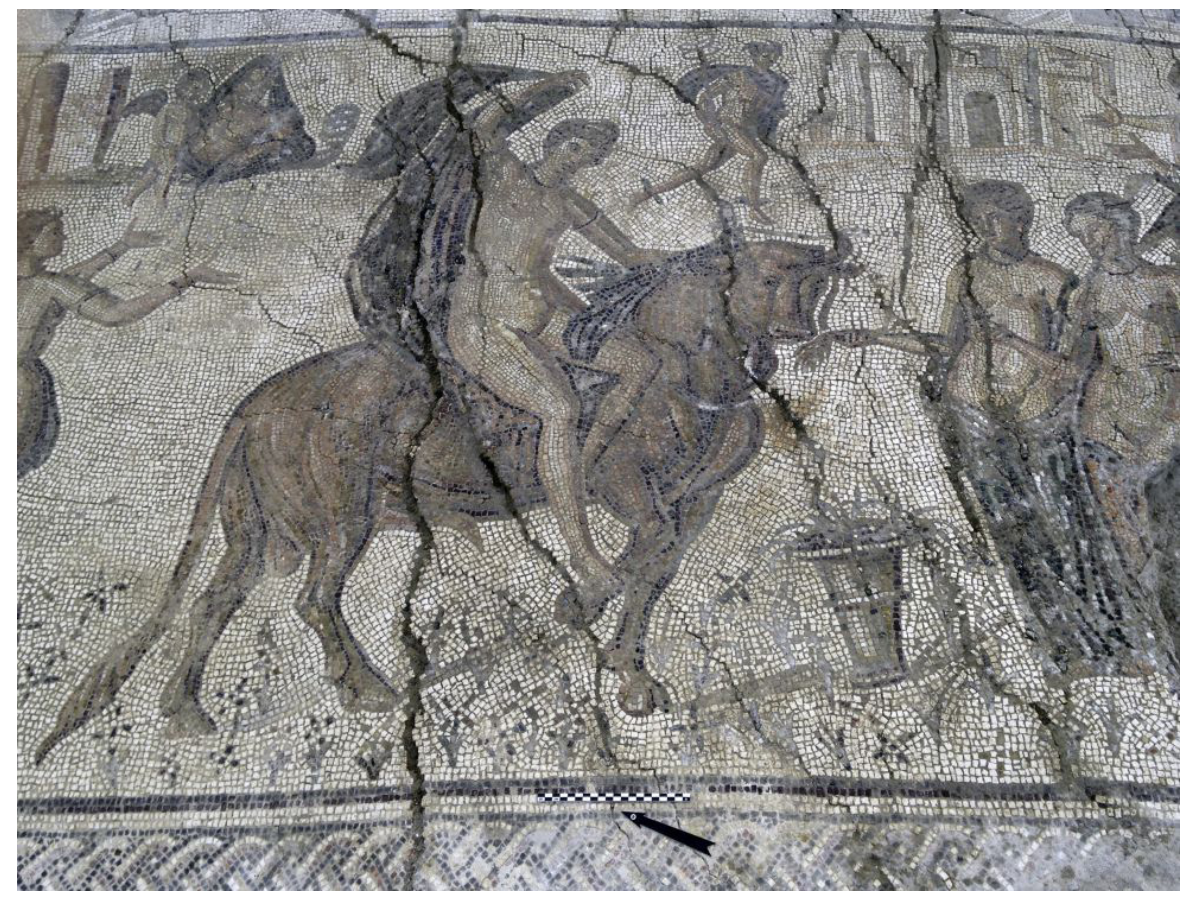

In this line, there are several servants who contemplate the initiative of Europe having climbed into the rump of the bull, which the two on the right approach with flowers in their hands without showing any distrust of the apparent meekness of the animal, as described Ovid (Ov.met. II, 855), while the one on the left with arms raised does seem startled at the attitude of Europe to intuit the risk posed to the Phoenician princess for her lack of caution with that unknown bull. This is in clear parallelism with the documented representation in the fragmentary mosaic, also of the conventus astigitanus, found in the villa of Fernán Nuñez (Córdoba), from the beginning of the $3^{\text {rd }}$ century A. D. (Blázquez 1981: $\mathrm{n}^{\circ} 32 \mathrm{pl}$. 32; Fernández-Galiano 1982: 17-22). In one of the rectangular panels with the legend of the abduction, preserved in the National Archaeological Museum (Fig. 3 ), one of the servants appears - in this case there are two - in the same position with /her back to the viewer exposing the buttocks, with identical attitude, gesturing with arms and hands raised forward as if trying to prevent and stop Europe. The figure of Europe sitting at the rump of the bull, is seen practically of profile in the direction to the right, still on the ground as indicated by the flowers, seated on a mantle, which barely covers /her left thigh inflating to /her back without arching over the head and whose end sheholds with her right hand raised, while clinging with its left to the right horn of the animal ${ }^{6}$ also responds in both mosaics to the same model.
Figure 2

Detail of the Rape of Europe.

Photo: According to Sergio García Dils.

6 In the same position as one of the typological series of Nereids in Roman mosaics (Neira 2002: 137138), then, as we have already pointed out in another work (Neira 2013: 37-41 figs. 32-35), Europe, whether on land, in full sea crossing, is represented in different positions according to some of the types documented in the representations of Nereids. 
Figure 3

Mosaic from Fernán Nuñez (Córdoba). Photo: According to Gonzalo Cases Ortega (MAN).

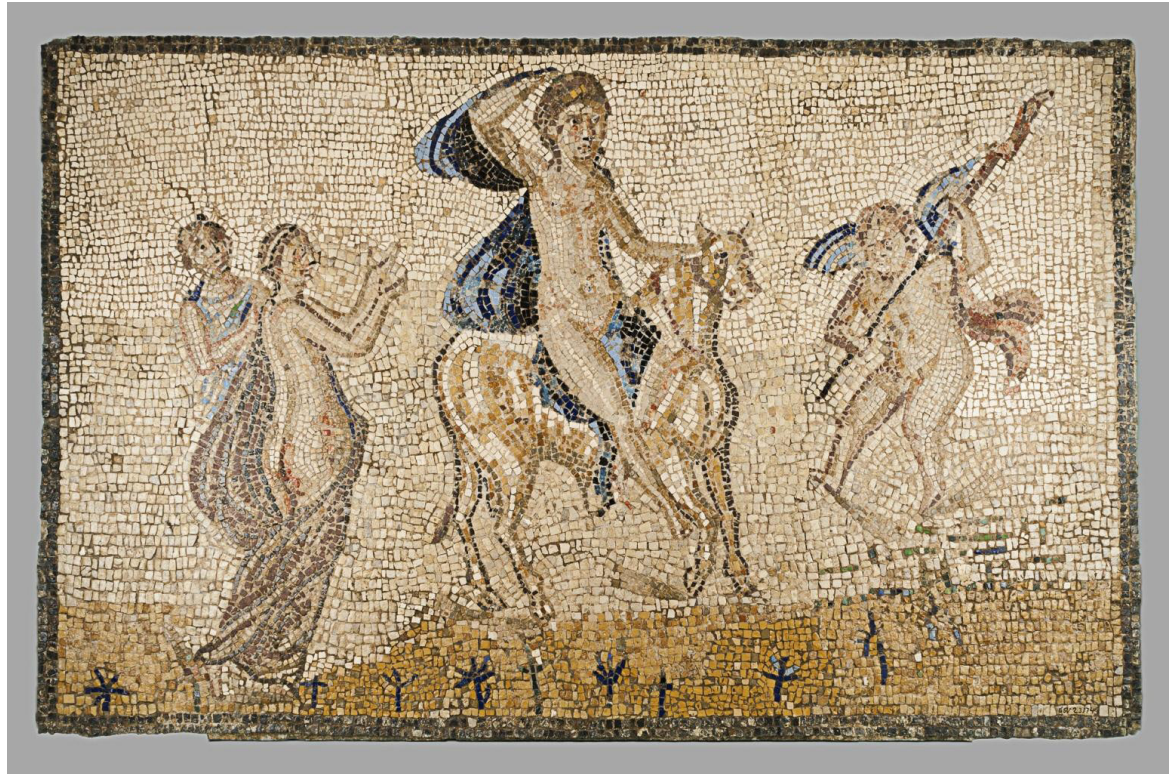

However, it is noteworthy that, although the female figure located on the left of Europe in both the Astigi mosaic and that of Fernán Nuñez responds to the reproduction of the same model, the restoration of the pavement and the recently published study of García-Dils de la Vega and Ordoñez (2019) reflects that this figure is actually in the astigitanus mosaic not one of the servants who accompanied Europe, but a representation of Danae (Fig. 4), when /she appears, with the hands extended forward, receiving the golden rain, simulated through vertical strokes, well noticeable after the restoration (García-Dils de la Vega Ordoñez 2019: 27-28 figs. 27-28), which fall from the image of the mature and bearded bust covered by a mantle, undoubtedly, Zeus, who in the upper area of the rectangular field, wherein the background two groups of buildings rise, figure to the left of it next to the presence to novelty of an eros.

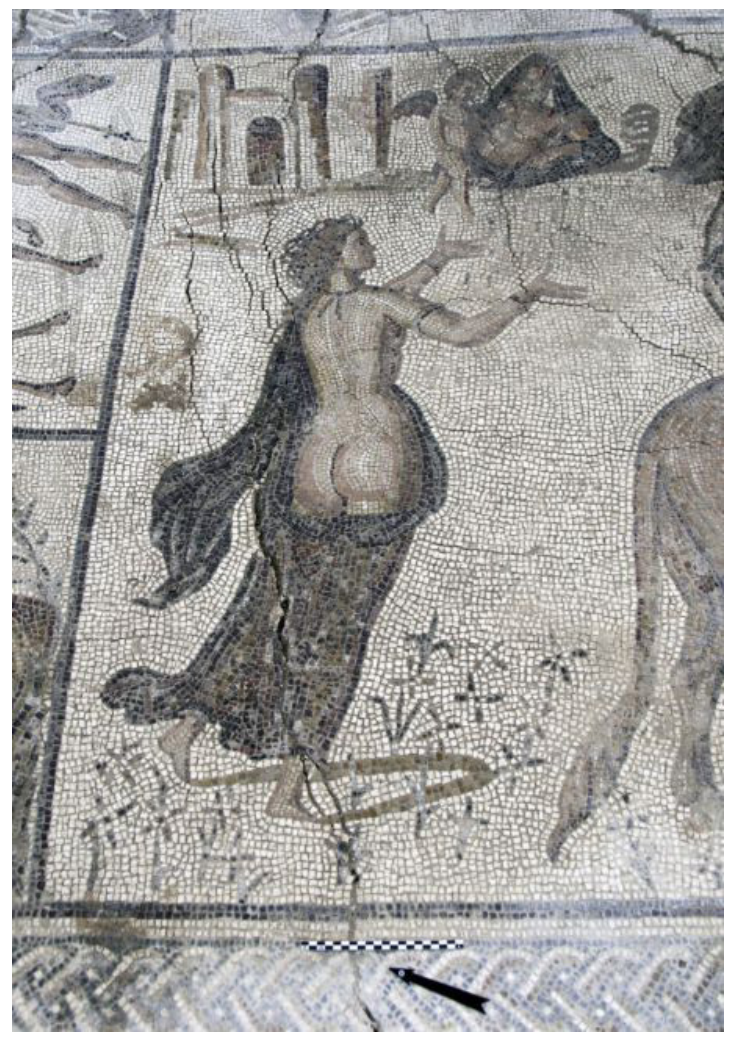


It is worth highlighting the unusual character of this representation of Danae, who usually appears to be seated receiving the golden rain in which Zeus metamorphosed, as shown in the well-known mosaic of the Loves of Italica or in the later of Bayreuth and Ouled Agla (López Monteagudo 1998: figs. 1-2, 5), although it also appears standing on one of the emblemata of the pavement so called of the horses of the Antiquarium of Carthage (Salomonson 1965: fig. 52 pl. XLVIII, 3), but seen from the front with the naked bust, with the corresponding horse behind her in the background, raising her himation to receive the rain with which, according to the myth, a cloud-shaped Zeus would fertilize /her.

In this regard, it should be noted that the conversion of the original figure of one of the accompanying servants of Europe, as documented in the mosaic picture of Fernán Nuñez, in a representation of Danae, with the aim of including one more legend Zeus Loves on the astigitanus pavement of the Plaza de Armas, undoubtedly reflects the adaptation of the images to different scenes and pavements by the mosaic artisans, although such adaptation was not always correctly resolved. It is the case of Danae in the mosaic from Écija (Seville), since, despite the incorporation of the bust of Zeus, and an eros, in the upper area, from where the golden rain falls towards the female figure in the form of short vertical strokes, identifying her without a doubt as the daughter of Acrisius and future mother of Perseus, her female figure stands on the same ground of flowers that Europe and her servants, according to the legend, and as in the scene of Fernán Nuñez, which seems to evidence the original identity of this female depiction and its subsequent conversion /into Danae and not vice-versa.

Similarly, the representation of the Ganymede legend in this astigitanus mosaic is rare (Fig. 5). The young man appears, standing, on his back, with a mantle that falls down his left side, practically naked, with the characteristic Phrygian cap, a large pedum and a recipient, possibly a patera, giving the eagle a drink, which appears above a pedestal, an ara, exercising, once consummated the rapture, as cupbearer of the god in the Olympus, as the literary sources recount (Sichtermann1988: 154-169). However, it is necessary to point out that it is the least common image in the Roman mosaics, where the legend of Ganymede acquired a great success, mostly capturing the approach of the god turned into

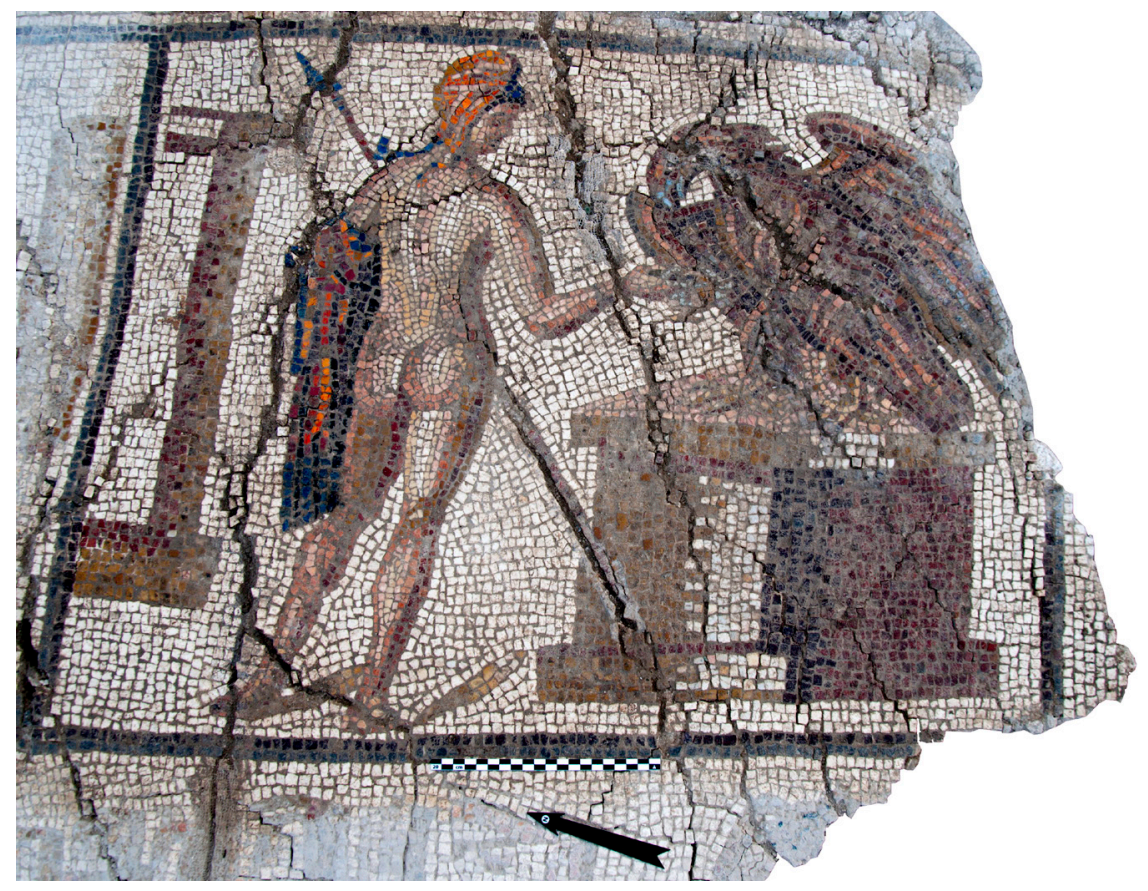

Figure 5

Ganymede detail in the astigitanus mosaic. Photo: According to Sergio García Dils. 
an eagle towards the young man and, in particular, the instant of the abduction with both already in flight, as evidenced years ago in a Foucher's study (Foucher 1979: 155-168), as reflected in another astigitanus pavement that also contains scene on the rape of Europe (López Monteagudo 2001: 133-146).

The scene of the post-rape episode and, consequently, the integration of Ganymede, already immortal, as a cupbearer in the Olympic sphere embodied in the mosaic of Zeus' Loves is well documented in the attic vases painting of red figures between the $6^{\text {th }}$ century and $4^{\text {th }}$ century $B C$, however, with the anthropomorphic figure of the god (Sichtermann 1988: no. 60, 63-64), instead of in the form, later, of an eagle, in paintings, reliefs and, especially, in Roman-era gems (Sichtermann 1988: no. 139-169). And so it also appears on two pavements of the second century AD, the fragmentary mosaic of the domus so called of "The Buffet Supper", Antiocheia (Levi 1947: 130-132 pl. 24), in an outdoor landscape indicated by a large tree (Fig. 6), and in one of the compartments of the Italica mosaic of the Loves that is preserved in the Palace-Museum of the Countess of Lebrija (Blanco 1978: $\mathrm{n}^{\circ} 1 \mathrm{pl}$. 5.2) on a neutral background as in the astigitanus (Fig. 7), although in both parallels, Ganymede appears in front of the viewer, slightly from three quarters to the left, towards the eagle ${ }^{7}$, captured in reverse than in the astigitanus mosaic.

Figure 6

Mosaic of the House of Buffet Super.

Antiocheia. Detail.

Photo: Courtesy of Javier Cabrero

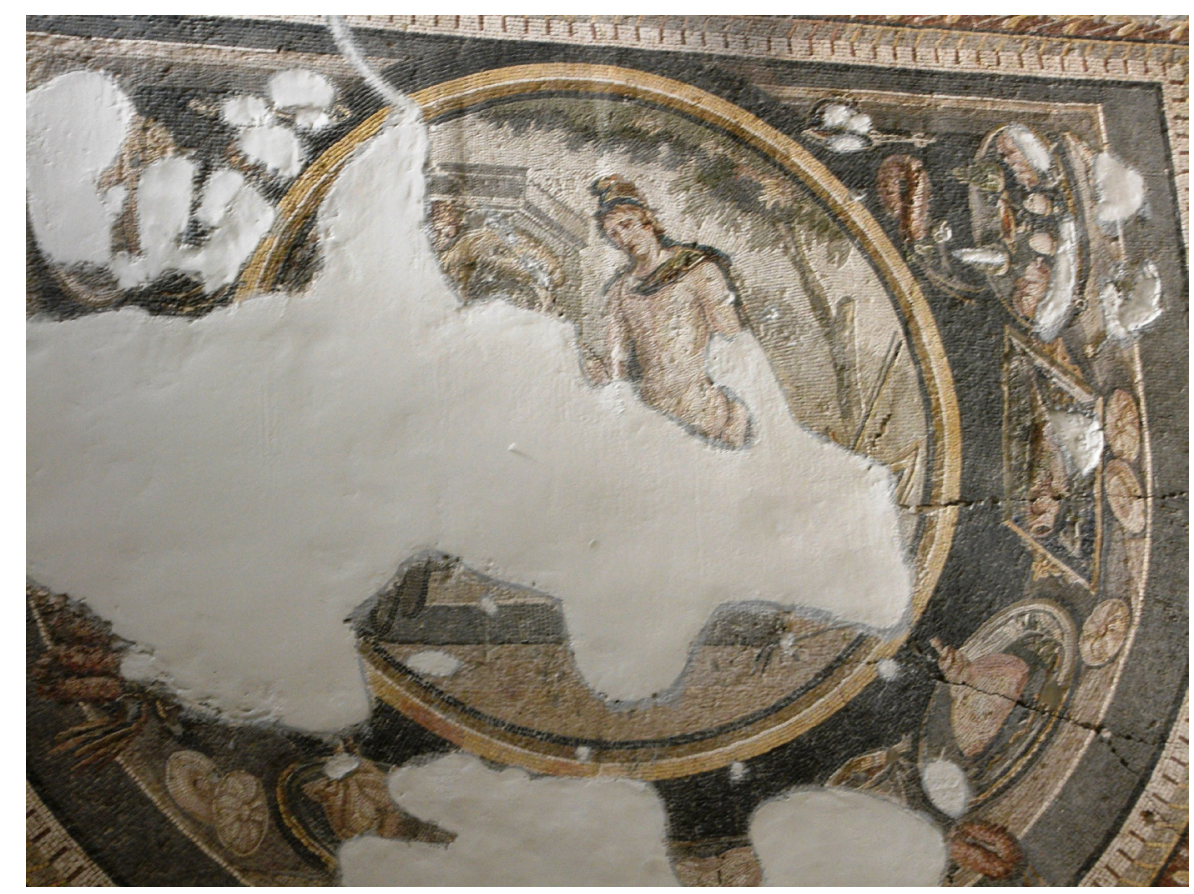

In this regard, another mosaic (Neira 2018: 21) from a private collection in Belgium, which is kept on loan in the Label Gallery, panel located in gallery 162 in the room dedicated to Roman sculpture in the Metropolitan Museum of Art in New York (http://www.sedefscorner.com/2013/07/slow-art-day-atmet.html), probably from the territories of the Roman provinces of the eastern Mediterranean, shows Ganymede, wearing a Phrygian cap and a mantle that leaves part of his body exposed, sitting on a rock, seen practically in profile, drinking from a container that holds the eagle in his right hand, which appears on his right, while posing his left hand on the wings of the bird, in a scene

7 Equally standing, practically naked, since the mantle falls down his back. 


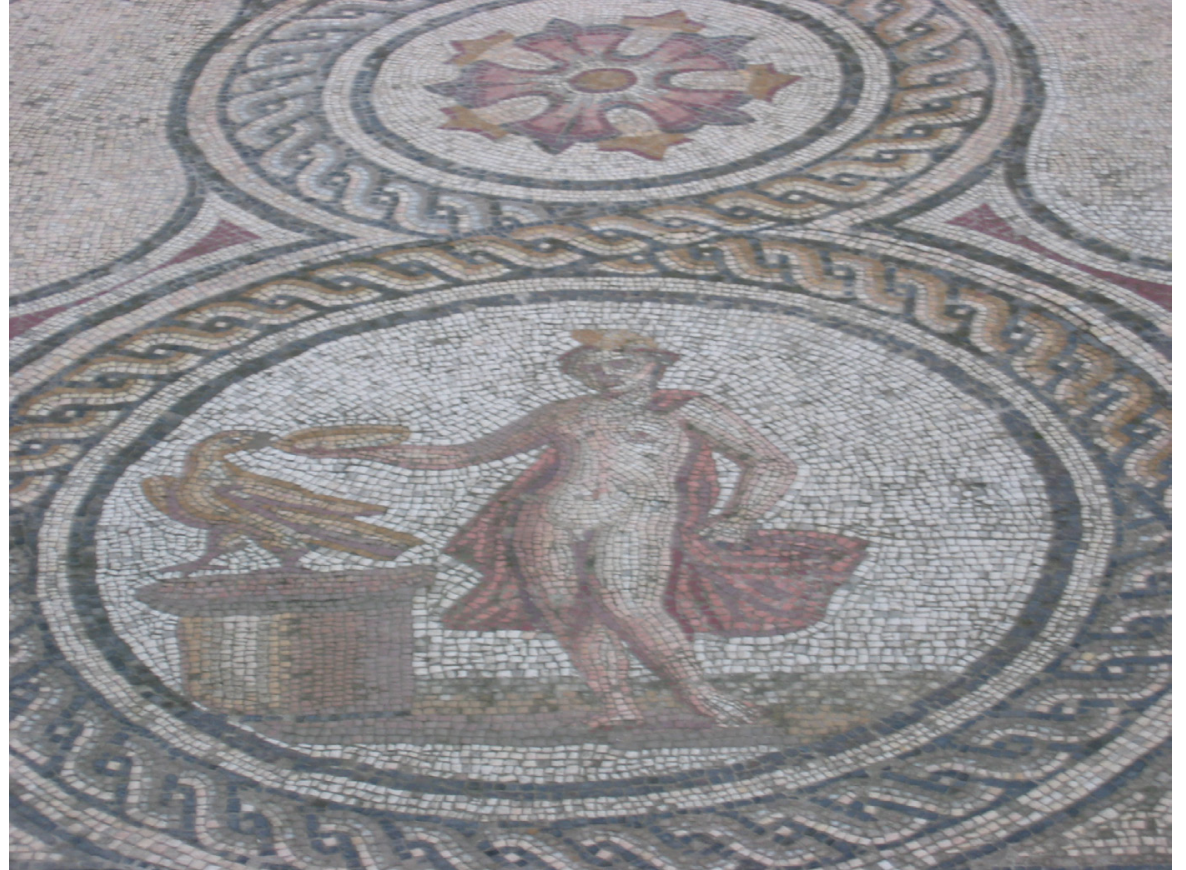

reminiscent of documented representations in several Roman gems (Sichtermann 1988: nos. 154, 158, 165). At the bottom of the figurative field the inscription NEIKIA $\Sigma$ ЕНФФОЕЕТН $\Sigma$ EN appears in reference to who made (Hurwit 2015: 22-23) or commissioned the mosaic (Fig. 8).

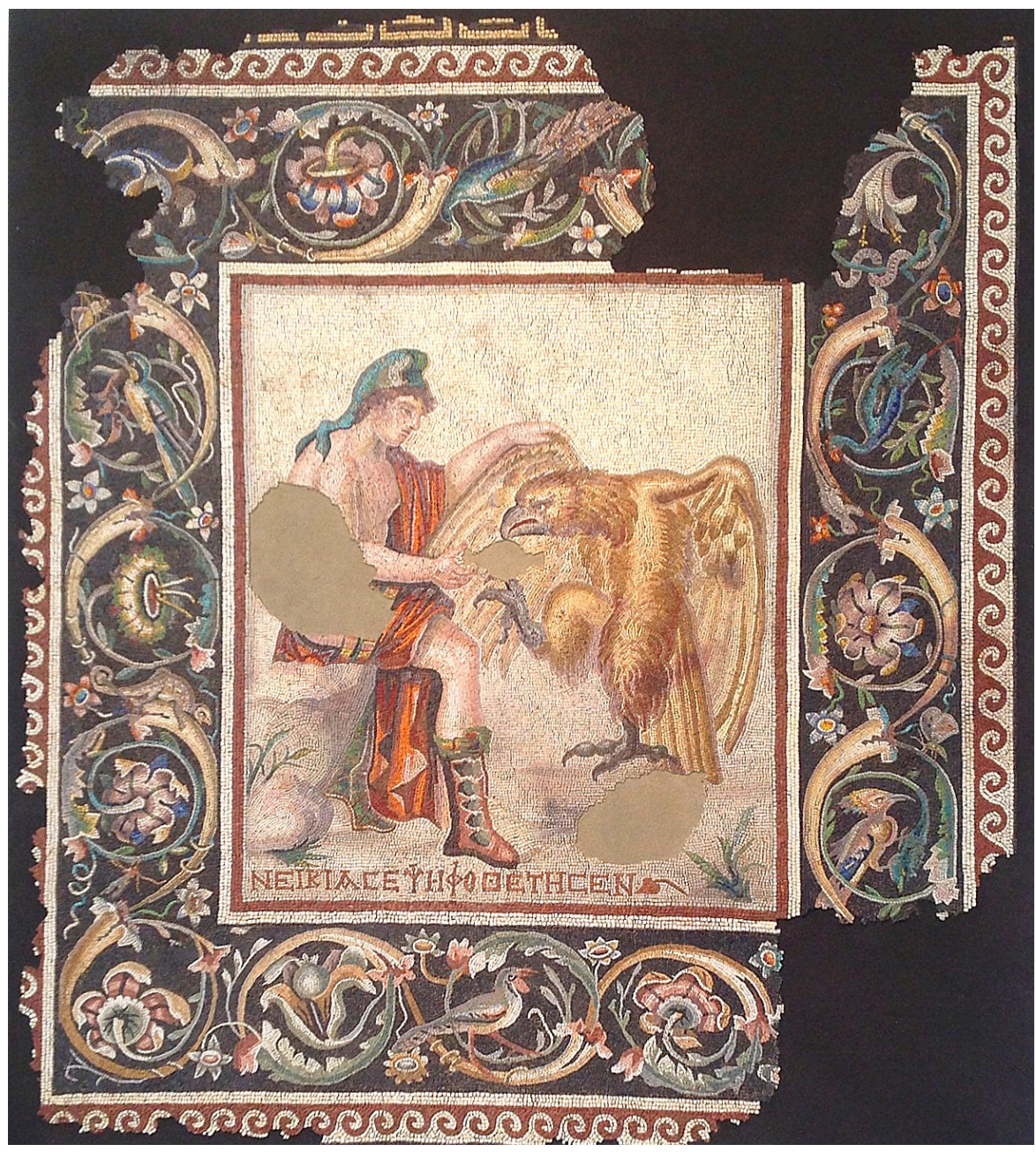

Figure 7

Ganymede detail. Mosaic from Italica. Photo: Luz Neira

Figure 8

Ganymede mosaic. Metropolitan Museum of Art in New York. Photo: http://www.sedefscorner.com/2013/07/ slow-art-day-at-met.html 
On its original provenience, the analysis of the framing edges of the figurative table is of special relevance. In this sense, and although the outermost band is barely visible, decorated with a geometric pattern in black tiles on an ocher background, the line of posts with incomplete winding is very revealing (Décor I : pl. 101a) in red tiles on a white background, which is documented with profusion in Antioch mosaics (Levi 1947), among others in the mosaic of The Boat of Psiches, from the $3^{\text {rd }}$ century AD, and in a large mosaic of Tarsus, about $200 \mathrm{~km}$ from Antioch, also from the first half of the $3^{\text {rd }}$ century AD (Cimok 2005: 50-51; 48-49, respectively), as well as in several mosaics of Zeugma, that of Poseidon with Oceano and Tethis, that of the bust of Dionysus, that of the representation of Ge, those of the Muses and the of Paideia, the wedding of Dionysus and Ariadne, and those of Achilles and Theonoe (Önal 2009: 28-29, $60,70-71,73-75,87,90)$. Next, a second, wider border appears, a thick border of acanthus scroll, decorated inside with flowers and birds, on a black background, which is equally well documented in above mentioned mosaics of the same origin, among others in the site of Tarsus, around the paintings depicted with representation, the most common, of the Rape of Ganymede and Orpheus, with flowers between the scrolls, in the mosaics of Eros and Psyche, with oceanic masks and fruits, and Women at breakfast, with ocean masks and hunter erotes, both from Zeugma (Önal 2009: 40, 48-49) and in the famous Paris' Judgment of Antiocheia, from the beginnings of the $3^{\text {rd }}$ century AD, preserved in the Louvre (Levi 1947) where, according to a greater coincidence, they are also represented various birds.

For all the above, the depiction of Ganymede in the astigitanus mosaic, it is a unique scene in the mosaics, since, as recalled, it not only differs from the most frequent with the same episode of the rapture, but which even differs from those closest images with the young Ganymede giving the eagle perched on an ara, already in Olympus, because even while standing equally in both the Italica and the Antiocheia mosaic, he presents himself with his back to the viewer.

In this regard, it is therefore a unique mosaic, with parallels, however, very close to some of the geometric and figurative motifs, which leads us to identify the same workshop that, according to of the geometric tapestry with a triaxial composition of adjacent cubes and the figure of Leda, it would have also worked on the fragmentary mosaic of the Triumph of Dionysus found in the Place of Santiago. This mosaic allows us also to acknowledge, at least, the roaming of artisans and the use of cartons of identical models for the representation of Europe and one of its servants in the aforementioned fragmentary mosaic of the villa of Fernán Nuñez (Neira 2019), nevertheless following a model for the representation of Ganymede that constitutes a hapax within the Roman mosaics. 


\section{Bibliography - Kaynaklar}

\section{Blanco 1978}

Blázquez 1981

Blázquez 1999

Cimok 2005

Décor I

Fernández-Galiano 1982

Foucher 1979

García-Dils de la Vega -

Ordoñez 2019

Hurwit 2015

Levi 1947

López Monteagudo 1998

López Monteagudo 2001

López Monteagudo -

San Nicolás 1995

Neira 2002

Neira 2013

Neira 2018

Neira 2019

Önal 2009

Salomonson 1965

San Nicolás 1999

San Nicolás 2005

San Nicolás 2010

Sichtermann 1988

Vargas Vázquez et al. 2017

Wattel-de Croizant 1995
A. Blanco Freijeiro, Mosaicos romanos de Itálica (I), Corpus España II, Madrid.

J. M. Blázquez, Mosaicos romanos de Córdoba Jaén y Málaga, Madrid.

J. ${ }^{a}$ Blázquez,"El mito griego de Leda y el Cisne en los mosaicos hispanos del Bajo Imperio y en la pintura europea”, Sautuola 6, 555-565.

F. Cimok, Mosaics of Antioch, İstanbul.

C. Balmelle - M. Blanchard Lemée - J.Christophe - J.-P. Darmon - A.-M. Guimier Sorbets - H. Lavagne - R. Prudhomme - H. Stern, Le Décor Géométrique de la Mosaïque Romaine I, Paris, 1985.

D. Fernández Galiano, "Nuevas interpretaciones iconográficas sobre mosaicos hispanorromanos”, Museos 1, 17-27.

L. Foucher, "L'enlèvement de Ganymède figuré sur les mosaïques”, AntAfr 14,155-168.

S. García Dils de la Vega - S. Ordoñez, El mosaico de los Amores de Zeus de la Plaza de Armas de Écija. Un nuevo pavimento musivo de colonia Augusta Firma, Écija.

J. M. Hurwit, Artists and Signatures in Ancient Greece, Cambridge.

D. Levi, Antioch Mosaic Pavements, Princeton.

G. López Monteagudo, "Sobre una particular iconografía del triunfo de Baco en dos mosaicos romanos de la Bética", AnCord 9, 191-222.

G. López Monteagudo, "Los mosaicos romanos de Écija (Sevilla). Particularidades iconográficas y estilísticas", D. Paunier - Ch. Schmidt (eds.), LMGR VIII, 30-146.

G. López Monteagudo - M. P. San Nicolás, "El mito de Europa en los mosaicos hispano-romanos. Análisis iconográfico e interpretativo", EspacioHist II, 8, 424-438.

L. Neira, La representación del thiasos marino en los mosaicos romanos. Nereidas y tritones, Madrid.

L. Neira, "Desnudo y atracción en los mosaicos. Venus, Europa y las nereidas", L. Neira (coord. y ed.), Desnudo y Cultura. La construcción del cuerpo en los mosaicos romanos, Madrid, 33-47.

L. Neira, "Mosaicos de los conventus hispalensis y astigitanus", J. Bermejo - J. Campos (coords.), Corpus Urbium Baeticorum. Conventus hispalensis y astigitanus, I y II. Huelva, Onoba Monografías, 2, 417-444.

L. Neira, "Notas sobre la identificación de talleres musivarios y cartones en la Baetica. A propósito de algunas representaciones en mosaicos de los Conventus Cordubensis y Astigitanus", Hispania et Roma: Estudios en homenaje al profesor Narciso Santos Yanguas, Oviedo, Servicio de Publicaciones de la Universidad de Oviedo, 349-359.

M. Önal, A Corpus Zeugma Mosaics, İstanbul.

J.W. Salomonson, La mosaïque aux chevaux de l'Antiquarium de Carthage. La Haya.

P. San Nicolás, "Leda y el cisne en la musivaria romana", Espacio, Tiempo y Forma, Serie I, Prehistoria y Arqueología, Tomo 12, 347-387.

P. San Nicolás, “Sobre una particular iconografía de Leda en el mosaico hispano de Écija”, LMGR IX, 975-985. Mª Pan Nicolás, “Zeus/Júpiter y Antiope en los mosaicos romanos”, EspacioHist 23, 497-518.

H. Sichtermann, "Ganymedes”, LIMC IV, 1/2. Zürich/Münich.

S.Vargas Vázquez - G. López Monteagudo - S. García-Dils de la Vega, Mosaicos romanos de Écija (Sevilla). Corpus España XIV, Madrid-Écija.

O. Wattel-de Croizant, Les mosaïques représentant le mythe d'Europe ( $\mathrm{I}^{\mathrm{er}}-\mathrm{VI} \mathrm{I}^{\mathrm{e}}$ siècles): évolution et interprétation des modèles grecs en milieu romain (De l'archéologie à l'histoire), París. 